\title{
A PROPOSAL FOR RESEARCH FRAMEWORK BASED ON THE THEORETICAL ANALYSIS AND PRACTICAL APPLICATION OF MLQ QUESTIONNAIRE
}

\author{
Maja Strugar Jelača
}

University of Novi Sad, Faculty of Economics Subotica, Republic of Serbia

$\bowtie$ m.strugar.jelaca@ef.uns.ac.rs

\section{Radmila Bjekić}

University of Novi Sad, Faculty of Economics Subotica, Republic of Serbia

$\triangle$ rstojanovic@ef.uns.ac.rs

\section{Bojan Leković}

University of Novi Sad, Faculty of Economics Subotica, Republic of Serbia

$\bowtie$ bojan.lekovic@ef.uns.ac.rs

UDC

005.322:31

6.46

Review

paper

\begin{abstract}
Leadership is a topic that attracts the attention of a large number of scientists and researchers who in their papers examine the issues of effective leadership. During previous research in this area different methodologies were used, but in recent decades one of the most prominent is MLQ questionnaire (Multifactor Leadership Questionnaire - MLQ), which examines three styles of leadership: transformational, transactional and passive leadership. The paper analyses the predominating attitudes in this area, theoretical explanation of MLQ questionnaire components and empirical results of previous applications. Founded on the obtained theoretical basis, the paper suggests future research framework in order to examine implementation of certain leadership styles from the MLQ questionnaire depending on the business environment which can vary from stable to uncertain, as well as their relationship with the achieved level of firm innovativeness. Thus, the aim of this paper is to define research framework that will be applied in a future research on an adequate sample of medium and large companies on the territory of the Republic of Serbia.
\end{abstract}

Received: Keywords: leadership styles, MLQ questionnaire, environment 09.12.2016. uncertainty, firm innovativeness

Accepted: 23.01.2017.

JEL classification: L20 


\section{Introduction}

Leadership is a topic that has been taking central place in scientific research for decades. It is subject to a large number of scientific and research papers by prominent social sciences authors. Striving to find the balance between different styles of leadership and provide maximum efficiency and satisfaction to both leaders and followers has caused the emergence of various theories of leadership and development of research instruments focused on testing leadership styles. The subject of this paper is an upgraded version of Multifactor Leadership Questionnaire (MLQ5X). MLQ analyses three styles of leadership: transformational, transactional and passive (laissez faire) leadership, as well as leadership outcomes (extra effort, efficiency and satisfaction). The framework of contemporary research on leadership is mostly related to the distinction between transactional and transformational leadership. Transactional leadership includes management activities, while transformational leadership involves entrepreneurial leadership directed towards a goal and it represents essential dynamic component of leadership. According to Bernard Basu, transactional leader is a person who motivates people to complete the task and reach the goal and who provides precise feedback (Bass, 1997). Transactional leadership is based on relations and information exchange, with precise mechanisms that can motivate participants to direct their efforts so that the implicit or explicit objectives are achieved. On the other hand, transformational leader is the one who motivates and inspires people to step outside their usual business routine.

The further tendency of research focuses on analysis of how cooperation between leaders and followers affects the firm innovativeness and whether it depends on environmental uncertainty. The first part refers to theoretical analysis of MLQ questionnaire, the second part shows some of the previous empirical studies using the MLQ questionnaire and the results obtained. Finally, the third part uses the questionnaire to provide a conceptual framework for future research leadership behaviour in medium and large companies on the territory of the Republic of Serbia.

\section{Theoretical Background}

In most studies on various theoretical concepts of leadership MLQ questionnaire was applied (Lowe et al., 1996, Yukl, 1994, p. 353). Its first use dates 38 years back (Burns, 1978), and it has significantly intensified recently (Dumdum et al., 2002). Since the appearance of MLQ questionnaire, it has been revised several times in order to find a better way of measuring the components due to the fact that there was a concern about psychometric properties of the questionnaire. The latest version of the questionnaire (MLQ-5X) was developed based on results of the 
previous studies in which its previous version was used. The questionnaire analysed implementation of three theoretical leadership concepts, such as:

1. Transformational leadership, which relates to the behaviour of leaders who emphasise motivation as a very important factor and consequently cause the motivation of followers through the creation and presentation of informative vision of the future (Bass, 1997). Over the past decade, the theory of transformational, charismatic and visionary leadership have begun to dominate both in the scientific literature on leadership and in practice. These theories are increasingly important in today's business environment, since they put an emphasis on the changes that are inevitable, as well as an adequate relationship between leaders and followers based on morality, ethics and emotion in order to complete the identification of followers with leaders in order to accept their beliefs and vision of the future. Often, leaders who emphasise the transformational leadership style are being called change agents (Rowold \& Heinitz, 2007, p. 122), as they represent the key individuals who identify new trends in the environment (Birkinshaw et al., 2008), and thus direct the innovative behaviour. They support initiatives related to the change in business practices, business processes or organizational structures (Vaccaro et al., 2012, p. 32); changing everyday scope of work through identifying new business activities and implementation of new business concepts based on a more flexible business process.

2. Transactional leadership stands in contrast with the transformational leadership which motivates the followers by appealing to their own interests. This style of leadership also involves values, but these are the values that are important for the process of exchange, such as honesty, responsibility and reciprocity (Yukl, Van Fleet, 1992: 175-176). Transaction leader, according to Bernard M. Bass, is a person who motivates people to perform the task, achieve the goal and provide precise feedback (Bass, 1997). Transactional leadership is based on relations and exchange information with the precise reward mechanisms that can motivate participants to direct their efforts so that the implicit and explicit goals could be achieved (Bass, 1997). Leaders who apply this style promote strengthening of individual interests of both themselves and their followers; they tend to monitor, inspect results and establish goals (Bass \& Avolio, 2000).

3. Laissez-faire leadership is such a style in which leaders avoid making decisions, disclaim responsibility and do not use their authority (Antonakis et al., 2003, p. 265). It is believed that this referred style of leadership is the least present in the current business environment and increasingly losing importance, because it represents a passive and ineffective style. It is often referred to as non-leadership, because there is no transaction, nor agreement with the followers. 
The analysis of the mentioned leadership styles involves the analysis of the individual nine components grouped into three groups: the first group consists of 5 components that relate to transformational leadership, the second group consists of 3 components related to transactional leadership, while the third group consists of two components that refer to laissez-faire leadership. In addition, MLQ questionnaire analyses outcomes of leadership as well.

Transformational leadership is comprised of idealised influence (attributed) (IA), idealized influence (behaviour) (IB), inspirational motivation (IM), intellectual stimulation (IS), individualized consideration (IC), (Bass \& Avolio, 1995, 2004). The first component (IA) identifies leaders who are able to build trust in their followers. They inspire their followers and focus on the interests of the group and all members of the group, putting them ahead of their personal interests. In this way, these leaders become reference models for their followers. The second component (IB) identifies leaders who act fairly. Under this component the following is evaluated: cooperation between leaders and followers, leaders' selfcontrol, morale, and self-efficacy. The existence of a shared vision and realising the vision in an ethical and moral way is highly valued here. The third component (IM) identifies leaders who inspire others. Leaders inspire their followers by common goals and creating a climate of trust and mutual understanding. They promote a common vision and find ways to achieve adequate vision recognizing opinions of their followers. The fourth component (IS) includes questions examining the extent to which the leader accepts the idea of the followers and encourages them to change the status quo through review of critical hypothesis (Tejeda, Manuel J. 2001). This component is primarily related to the leaders who are able to encourage innovative thinking. By intellectual stimulation transformational leaders can help others to think about problems in a different way and come up with some new, improved solutions. A key indicator of the efficiency of a leader is to what extent one is able to empower his/her followers to work without his presence and direct participation. The fifth component (IC) involves defining and respecting individual needs of the followers by the use and development of their forces in order to exploit their maximum potential.

Transactional leadership is comprised of contingent reward (CRW) and active management by exception (MBEA) (Bass \& Avolio, 1995, 2004). Conditional remuneration refers to the leaders' focus on clearly defined tasks, and rewarding the followers with material or immaterial rewards if they fulfill their obligations. Active management by exception involves actively monitoring actions by the leaders and detecting deviations from rules and standards, defining and taking corrective action in order to avoid deviations on the path to the standard goal.

A laissez-faire $(L F)$ leadership was conceptualised as essentially the absence of leadership (Bass, 1985). A passive leadership is comprised of passive management by exception (MBEP) and avoiding the involvement (LF) (Bass \& Avolio, 1995, 
2004). Passive management by exception relates to reactive behaviour of a leader. Leaders intervene only after the problem occurs when the mistake was already made. Leaders who are passive follow the saying if it is not broken, do not fix it and wait until the problem becomes a serious one and then take corrective actions. Avoidance of participation is typical of passive leaders. They avoid responsibility that the position of the leader entails, they do not offer enough data to their followers, do not provide any feedback, are absent when they are most needed, avoid making decisions and react to problems too late.

Outcomes of leadership: Transformational and transactional leadership are tied to the group's success, which is measured by MLQ questionnaire. Part of the questionnaire relating to the leadership outcomes should point out whether followers believe that their leader knows how to motivate them, how much the leadership style that is realized is effective at different levels of the company and whether the followers are satisfied with the leadership methods used.

The three outcome criteria which are included in the MLQ are Followers' extra effort (EEF), the Effectiveness of leader's behaviour (EFF), and Followers' satisfaction (SAT) with their respective leader. Extra effort refers to behaviour which implies that the leader is investing extra effort to encourage others to do more than what they expect they can, reinforcing the desire and self confidence among followers that they can succeed and increase the willingness to make the effort to work better and more. The effectiveness of leader's behaviour means that leaders are effective in meeting the needs of employees, in representing their supporters in front of a higher authority, in meeting organizational requirements and that the leader leads a group which is effective. Satisfaction as a result of leadership refers to whether the leader uses satisfactory techniques and methods of management and whether he/she manages the followers satisfactorily.

\section{Some Results of the Application of MLQ Questionnaire until Today}

Based on the analysis of some of the previous empirical research in this area, it can be said that there is a strong empirical evidence that transformational leadership, more than any other leadership style, is highly effective (Judge \& Piccolo, 2004; Lowe et al., 1996 Wang et al., 2011). The topic of empirical research in this area ranges from detailed statistical analysis of reliability of MLQ questionnaires to putting into relationship its components with a large number of different variables which measures business conduct and results of the company.

Some authors have analysed the use of different styles of leadership covered by MLQ questionnaire in terms of impact on the subjective (followers' perception of effectiveness, their extra effort, and their satisfaction) and objective performances (profit), where they came to the result that transformational leadership augmented 
the impact of transactional leadership on subjective performance (Rowold \& Heinitz, 2007, p. 121). Also, transformational leadership had an impact on profit, over and above transactional leadership (Rowold \& Heinitz, 2007, p. 121), whereas transactional leadership shows negative correlations to objective outcomes (Howell et al., 2005). Based on majority of empirical studies that give primacy to transformational style of leadership in terms of performances, Deinert et al. (2015) analysed in detail the relationship between the individual components of transformational leadership style and the actual performance of leaders such as leaders' abilities, skills, and achievement of the defined task. The results indicate that all of the components that describe transformational leaders were positively related to leader performance, but the strength of the effect varied (Deinert et al., 2015, p. 1107). Most of the research results indicate the existence of a link usually between transformational leadership style and performance achieved encouraging survival and the desired growth of the company. In addition, some authors have analysed the relationship between different styles of leadership and organisational learning on one hand and the generation of a large number of ideas on the other. It is assumed that the leaders who implement strategic process of organisational learning must possess and apply both behaviour concepts simultaneously, depending on the situation (Vera \& Crossan, 2004). Also, many authors point out that transformational and transactional leadership are one of the most critical factors influencing creativity of employees and their capacity to generate ideas for the company (Bass, 1985; Podsakoff et al., 1996; Yukl, 1999). However, empirical research on this topic leads to contradictory results: Deichmann and Stam (2015) in their study on to what extent transformational / transactional leadership motivates employees to generate ideas that will enable the company to realize the benefit show that both leadership styles indirectly encourage generation of ideas, depending on the employees' commitment and leaders' identification with the organisation. Other studies emphasise the absence or even a negative effect between implementation of transformational and transactional leadership style and organisation-focused idea generation (Jung et al., 2003, Nederveen et al., 2010; Rank et al., 2009). The existence of conflicting opinions in this area arises from the complexity of leadership and personal values beliefs so that the same leadership style can have very different effects on organisation-focused idea generation of followers (Kuhnert \& Lewis, 1987). To validate attitude of Kuhnert and Lewis, the authors Deinert et al. (2015) as a part of their study analysed the relationship between personality traits (neuroticism, extraversion, openness to experience, agreeableness, and conscientiousness) and components of transformational leadership style, and it was found that the Big 5 personality traits are directly linked to transformational leadership sub-dimensions. This research highlights the new topics for discussion and research directions from the perspective of the psychology of leaders and styles used. 
In the last four decades that the analysis has been carried out on numerous influences and relations of leadership styles with different variables of research, there have been conflicting views which style is the best. At the beginning of the research within this topic Burns (1978) points out that transformational and transactional leadership styles are the opposite ends of a continuum, while Bass $(1985,1997)$, however, views them as distinct dimensions, which allows a leader to be transactional, transformational, both, or neither. Today, more and more emphasis is placed upon the effective leadership model that includes appropriate combination of transformational and transactional leadership which can complement each other depending on the situation.

\section{Future Directions of Research - MLQ Framework for the Implementation of Questionnaires on the Territory of the Republic of Serbia}

The fundamental premise of our future research framework is the contingency approach to the theory of leadership from the aspect of environmental uncertainty, where the leaders of the company implement an effective style depending on the situation. Uncertainty of the surrounding in the modern businesses would be observed from the perspective of dynamism in the consumer, competitive and technological environment. The tendency for the analysis of the aforementioned hypothesis derived from attitude that an ideal strategic leader would be able to identify-and-exercise the leadership behaviours appropriate for the circumstances (Vera \& Crossan, 2004, p. 226). Therefore, it is assumed that companies that operate in an uncertain environment give primacy to the transformation leadership, while companies in a more stable business environment place more emphasis on transformational style. Given hypothesis arise from the author's attitudes that transformational leadership has a greater potential to address issues that are relevant in the modern work environment and uncertain (Lim \& Ployhart, 2004), and while consistently honoring transactional agreements, CEOs build an image of consistency among organisational members (Shamir, 1995). On the basis of studying theoretical positions, research hypothesis in the context of future research would be:

Research hypothesis No. 1: There is a difference in application of leadership style of management in medium and large companies on the territory of the Republic of Serbia, depending on the degree of uncertainty of the business environment.

Research hypothesis No. 2a: There is a positive correlation between a high degree of uncertainty of the business environment and implementation of transformational leadership style. 
Research hypothesis No. $2 b$ : There is a positive correlation between stable business environment and implementation of transactional leadership styles.

On the other hand, the use of combined leadership concepts would be analysed depending on the degree of firm innovativeness. Establishing a connection between the mentioned variables derives from the basic goal of leaders to provide permanent survival and success of the company, where it is considered that an organisation's ability to innovate is one of the determinant factors for organisations to survive and succeed (Doyle, 1998; Quinn, 2000). From the innovation perspective, the current researches within this area give the primacy to transformational leadership, because contemporary trends put before leaders the task to create innovative-oriented organisational climate that encourages constant exchange of information, and reward achieved innovative results. The establishment of such organisational climate requires the leader to be sensitive to change, understand the different disciplines and processes in order to implement changes in time and make more efficient combination of business processes. However, transactional leadership style is more tied to a stable business, with minimal disruption of the routine of work and responding only to the identified gap between planned and realized. This fact points to a very stiff and rigid way of organisational behaviour, which scarcely encourages flexibility and adaptability of an organisation and is more oriented towards maintaining the status quo than to innovating. The tendency to analyse combinations of the aforementioned styles and their effect on innovation follows from the foregoing as well as from the results of research conducted by Vaccaro, Jansen, Van Den Bosch and Volberda (2012, p. 28), which indicates the opposite, because statistically significant relationship of medium impact appears from the application of transactional leadership and innovative ways of managing in the sample of small and less complex companies. Justified observation of the joint application of styles derives from the attitude of Quinn (1988), who believes that the leader may excel transformational behaviours but may choose transactional behaviours when needed and vice versa. In empirical tests, using the transformational / transactional framework, researchers have found a high correlation between behaviours of transformational leadership and those of contingent reward leadership (e.g., Avolio et al., 1999; Bass \& Avolio, 1993), indicating that both sets of behaviours are likely to exist in the same individuals in different amounts and intensities (Bass, 1997). Based on that, future empirical hypothesis would be:

Research hypothesis No. 3: There is a connection between combined application of transactional and transformational leadership styles and the degree of firm innovativeness.

The parallel studies of three variables such as leadership styles, the degree of uncertainty in the surrounding and the level of firm innovativeness, results in the view that companies in a stable environment encourage less innovative activities 
that result in the offer of incremental innovations, for whose management transactional leadership is sufficient, while companies in an uncertain environment encourage more and more radical innovation in order to survive as much as possible through transformational leadership. As Tushmann \& O'Reilly (1996) point out, in the modern environment which is very dynamic and complex leaders need to be ambidextrous, that is to properly combine diverse courses of action, incremental and discontinuous innovation, exploration and exploitation, flexibility and control. Summing the current views and desired research hypothesis we have formed a research framework shown in the figure below.

Figure 1. Research frame

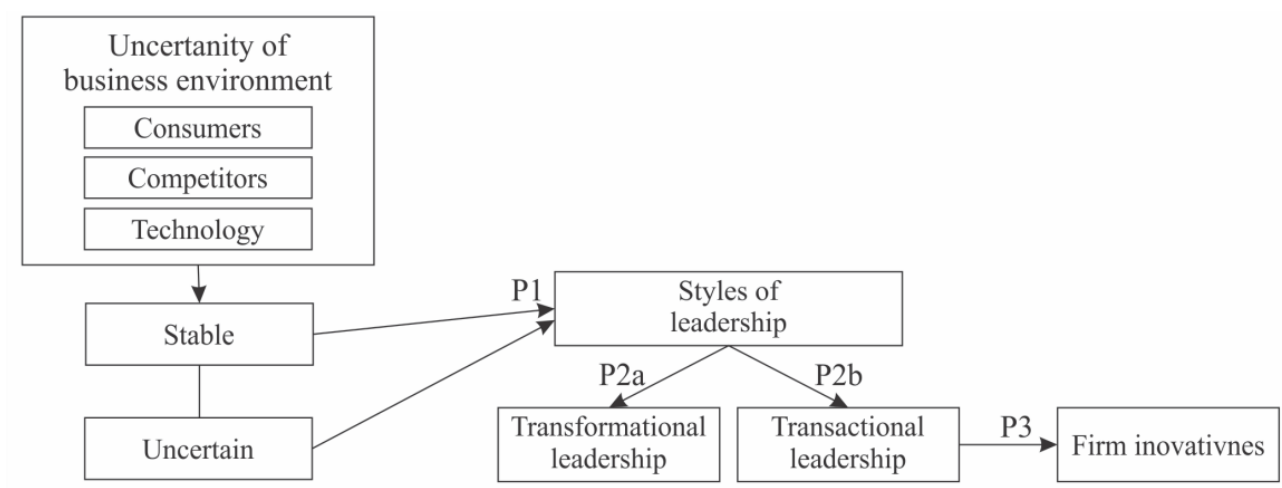

\section{Methodology for the future research}

Measurement of variables shown in the research frame would be conducted using:

- Standardised questionnaire MLQ-5X, in order to determine the extent of using transactional or transformational leadership in medium and large companies on the territory of the Republic of Serbia;

- Customised questions about the uncertainty of business environment from the survey Jaworski \& Kohli (1993), which would allow the ranking of the business environment of the surveyed enterprises in the Republic of Serbia in different activities from stable to uncertain environment;

- Specific questions about the degree of firm innovativeness taken from the questionnaire author Ahmed and Wang (2004) in order to establish product, process, market and behavioural innovativeness of surveyed companies.

The first variable in the research refers to the styles of leadership described by 45 questions, with 36 questions relating to nine components of leadership styles and 9 questions connected with the outcomes of leadership. The procedure for interpreting responses and style of leadership is as follows: a total of 45 questions 
from MLQ questionnaire that relate to the behaviour of a leader can be categorised into 9 groups. Each of these groups represents one of the leadership components (Avolio \& Bass, 1995, 2004), which are explained earlier in the text. The first five components of leadership are related to transformational leadership style, sixth and seventh component to transactional leadership, and the eighth and ninth to passive leadership. In addition to evaluating the style of leadership, evaluating the outcomes of leadership is done on the basis of issues that were classified into three groups: extra effort, efficacy (effectiveness) and satisfaction (Bass \& Avolio, 1995, 2004).

The second variable of the research is the degree of uncertainty of the business environment. The environment of an organisation is not homogeneous entity, but a complex combination of many factors that mutually influence the formation of dynamism and environment uncertainty. Therefore, this variable will be analysed from the perspective of changes in the context of the consumers' desire, new moves by competitive organisation and movement of technological innovation. Uncertain environment is defined as a business environment where it is very difficult to identify, measure or predict critical variables and where a causal link between the factors in the environment or environment and factors in organisation are very difficult to understand (Frederickson, 1983). Therefore, in such an environment, inclusiveness in decision-making is not possible given that the data are not always visible, but the future is unpredictable, which requires application of appropriate leadership style.

From the point of measuring the third variable of research, firm innovativeness, in most current researches the emphasis is placed mainly on the measurement of product innovativeness, but undermines the importance of factors, such as process innovation, strategic orientation towards innovation etc. (Wang \& Ahmed, 2004). As part of our research we aim to measure the firm innovativeness, and an organisation's overall innovative capability, i.e. the propensity or likelihood that an organisation produces innovative outcomes (Wang \& Ahmed, 2004). To measure this variable we will use 9 items (adapted from Wang and Ahmed, 2004) which explain the product, process, market and behavioural innovativeness. We will analyse whether a company is first-to-market; whether company's products from the perspective of consumers are considered new; compared with competing organisations, whether company has introduced more innovative products and services during the past five years, whether it is faster in this, as well as the implementation of new production processes; whether it constantly improves business processes and whether it had increased allocations for it.

For assessing transformational / transactional / laissez-faire leadership, uncertainty of the surrounding and the degree of firm innovativeness, questionnaires were carefully translated from Serbian to English by a professional and then back by a native English speaker. For each of the MLQ and dynamic 
environment and firm innovativeness items, respondents will express their opinion about leaders' behaviour, the degree of dynamism and innovation on a 5-point rating scale $(1=$ not at all, $5=$ frequently, if not always).

After conducting theoretical research process together with designing methodological framework, the next step will be carried out through empirical research: first step - the choice and determination of the statistical mass; second step - to collect data using the questionnaire method; third step - statistical analysis performed by using the statistical method and eventually testing research results.

\section{Conclusion}

Leadership is a critical factor in the success of modern organisations, but also a resource on which organisation can build and develop its competitive advantage. Leadership is a continuous process that constantly needs to be improved. There is no universal style of leadership appropriate in all situations. This is due to many internal and external factors that affect the style of leadership that will be adequate in a given situation. One of the most important factors that have the greatest impact is certainly environment in which the company operates. Bearing in mind that the leaders of the company apply effective leadership style depending on the situation, fundamental premise of our future research framework will be contingent approach to the theory of leadership from the aspect of environmental uncertainty.

Taking into account the fact that the current business environment is characterized by scientific and technological progress and constant changes, innovation is a condition for the survival and development of the organisation. The extent to which a company will be competitive, among other things, depends on the extent to which leaders are aware of the fact that only continuous learning, acquiring and application of new knowledge leads to innovation as a condition sine qua non for survival and development. Accordingly, the subject of our future research will be a parallel observation of leadership styles, the degree of environment uncertainty and the degree of firm innovativeness, where we try to prove the existence of connections between a stable environment, lower level of innovative activity (incremental innovation) and transactional leadership, as well as the relationship between uncertain environment, a higher level of innovative activity (radical innovation) and transformational leadership.

The most important is to find the balance between different styles of leadership and providing maximum efficiency and satisfaction for leaders and followers (followers) in a given situation, taking into account relevant factors, particularly environment and innovation, which have dominant influence on the selection of appropriate leadership style. 


\section{References}

Antonakis J., Avolio B. \& Sivasubramaniam N. (2003). Context and leadership: an examination of the nine-factor full-range leadership theory using the Multifactor Leadership Questionnaire. The Leadership Quarterly, 14(3), 261-295.

Bass B. M. (1985) Leadership and performance beyond expectations. Free Press. New York

Bass B. M. \& Avolio B. J. (1993) Transformational leadership, response to critiques in: Leadership theory and research perspectives and directions. Academic Press. New York, 49-80.

Bass, B. M. \& Avolio B. J. (2004) Multifactor leadership questionnaire - MLQ self-evaluation. Manual and sampler set (3rd ed.). Redwood City, CA: Mindgarden. 5-9.

Bass, B. M. (1997) Does the transactional-transformational leadership paradigm transcend organizational and national boundaries? American Psychologist, 52, 130-139.

Bass B. M. \& Avolio B. J., (2000) Multifactor Leadership Questionnaire, Retrieved from: http://www.mindgarden.com/documents/MLQGermanPsychometric.pdf Accessed on: June 1,2016

Burns, J. M. (1978) Leadership, New York: Harper and Row.

Birkinshaw, J., Hamel, G. \& Mol, M. J. (2008) Management innovation. Academy of Management Review, 33(4), 825-845.

Deichmann D. \& Stam D. (2015), Leveraging transformational and transactional leadership to cultivate the generation of organization-focused ideas. The Leadership Quarterly, 26, 204-219.

Deinert A., Homan A., Boerc D., Voelpel S. \& Gutermannan D. (2015) Transformational leadership sub-dimensions and their link to leaders' personality and performance. The Leadership Quarterly 1095-1120

Doyle, P. (1998) Innovate or Die. Marketing Business. 20, pp3.

Dumdum, U. R., Lowe, K. B. \& Avolio, B. J. (2002) A meta analysis of transformational and transactional leadership In B. J. Avolio \& F. J. Yammarino (Eds.), Transformational and charismatic leadership: The road ahead (pp. 35-66). Oxford, UK: Elsevier Science.

Frederickson, J.W. (1983) Strategic process research: Questions and recommendations. Academy of Management Review, 8, 565-575

Howell, J. M., Neufeld, D. J. \& Avolio, B. J. (2005) Examining the relationship of leadership and physical distance with business unit performance. The Leadership Quarterly, 16, $273-285$

Jaworski, B. \& Kohli, A. (1993) Market orientation: Antecedents and Consequences. Journal of Marketing, 57, 53-70.

Jung, D.I., Chow, C. \& Wu, A. (2003) The role of transformational leadership in enhancing organizational innovation: Hypotheses and some preliminary findings. The Leadership Quarterly, 14, 525-544.

Judge, T. A. \& Piccolo, R. F. (2004). Transformational and transactional leadership: A metaanalytic test of their relative validity. Journal of Applied Psychology, 89, 755-768.

Kuhnert, K.W. \& Lewis, P. (1987) Transactional and transformational leadership: A constructive/ developmental analysis, 12, 648-657.

Lim, B. C. \& Ployhart, R. E. (2004) Transformational leadership: Relations to the fivefactormodel and teamperformance in typical and maximum contexts. Journal of Applied Psychology, 89, 610-621.

Lowe, K. B., Kroeck, K. G. \& Sivasubramaniam, N. (1996) Effectiveness correlates of transformational and transactional leadership: A meta-analytic review of the MLQ literature. The Leadership Quarterly, 7, 385-425. 
Nederveen Pieterse, A., Van Knippenberg, D., Schippers, M. \& Stam, D. (2010) Transformational and transactional leadership and innovative behavior: Themoderating role of psychological empowerment. Journal of Organizational Behavior, 31, 609-623.

Podsakoff, P.M., MacKenzie \& Bommer H. W.(1996) Transformational leader behaviors and substitutes for leadership as determinants of employee satisfaction, commitment, trust, and organizational citizenship behaviors. Journal of Management, 22, 259-298.

Rowold J. \& Heinitz K. (2007) Transformational and charismatic leadership: Assessing the convergent, divergent and criterion validity of the MLQ and the CKS. The Leadership Quarterly, 18, 121-133

Quinn, R. E. (1988.): Beyond rational management: Mastering the paradoxes and competing demands of high performance. San Francisco: Jossey-Bass.

Quinn, J. B. (2000) Outsourcing Innovation: The New Engine of Growth. Sloan Management Review, 41(4), 13-28.

Rank, J., Nelson, N.E., Allen, T.D. \& Xu, X. (2009) Leadership predictors of innovation and task performance: Subordinates' self-esteem and self-presentation as moderators. Journal of Occupational \& Organizational Psychology, 82, 465-489.

Shamir, B. (1995) Social distance and charisma: Theoretical notes and an exploratory study. The Leadership Quarterly, 6, 19-47.

Tejeda, Manuel J. (2001), The MLQ revisited: Psychometric properties and recommendations. The Leadership Quarterly, 12(1), 22-31.

Tushman, M. L., O’Reilly \& C. A., III. (1996) Ambidextrous organizations: Managing evolutionary and revolutionary change. California Management Review, 38(4), 8-30.

Vaccaro, G.I., Jansen, J.P.J., Van Den Bosch, A.J.F. \& Volberda, W.H. (2012) Management Innovation and Leadership: The Moderating Role of Organizational Size. Journal of Management Studies, 49(1), 28-51.

Vera D., Crossan M. (2004) Strategic leadership and organizational learning. Academy of Management Review, 29(2), 222-240.

Wang, C. L. \& Ahmed, P. K. (2004). The development and validation of the organisational innovativeness construct using confirmatory factor analysis. European Journal of Innovation Management, 7(4), 303-313.

Wang, G., Oh, I. -S., Courtright, S. H. \& Colbert, A. E. (2011) Transformational leadership and performance across criteria and levels: A meta-analytic review of 25 years of research. Group \& Organization Management, 36, 223-270

Yukl, G. (1994) Leadership in organizations, Englewood Cliffs, NJ: Prentice-Hall.

Yukl, G. (1999) An evaluation of conceptual weaknesses in transformational and charismatic leadership theories. The Leadership Quarterly, 10, 285-305.

Yukl, G. \& Van Fleet, D. D. (1992). Theory and research on leadership in organizations. In M. D. Dunnette \& L. H. Hough (Eds.). Handbook of industrial and organizational psychology. (pp. 147-199). Palo Alto, CA: Consulting Psychologists Press.

\section{PREDLOG ISTRAŽIVAČKOG OKVIRA NA OSNOVU TEORIJSKE ANALIZE I DOSADAŠNJE PRIMENE MLQ UPITNIKA}

Apstrakt: Liderstvo je tema koja zaokupljuje pažnju velikog broja naučnika i istraživača koji u svojim radovima obrađuju problematiku efektivnog liderstva. Tokom dosadašnjih istraživanja $u$ ovoj oblasti, korišćene su različite metodologije, ali poslednjih decenija jedan od najzastupljenijih je MLQ upitnik 
(Multifactor Leadership Questionnaire - MLQ) koji ispituje 3 stila liderstva: transformaciono, transakciono i pasivno liderstvo. Predmet rada je analiza vladajućih stavova u ovoj oblasti, teorijsko obrazloženje komponenti MLQ upitnika i empirijskih rezultata njegove dosadašnje primene. $\mathrm{Na}$ osnovu dobijene teorijske baze, u radu je predložen budući istraživački okvir kako bi se ispitala primena pojedinih stilova liderstva iz ankete MLQ u zavisnosti od poslovnog okruženja koje može varirati od stabilnog ka neizvesnom kao i njihova veza sa ostvarenim stepenom inovativnosti preduzeća. Dakle, cilj rada je definisanje istraživačkog okvira koji će biti primenjen u budućim istraživanjima na adekvatnom uzorku srednjih i velikih preduzeća na teritoriji R. Srbije.

Ključne reči: stilovi liderstva, MLQ upitnik, neizvesnost okruženja, inovativnost organizacije

\section{Authors' biographies}

Maja Strugar Jelača, $\mathrm{PhD}$, is a teaching assistant at the Department of Management, Faculty of Economics in Subotica, University of Novi Sad, where she works since 2007. She teaches bachelor's course Strategic Management and master's courses Innovation Management and Tourism Management. In 2015 she defended her doctoral thesis on the topic: "The impact of the innovation dynamics on a model of management activities". She is an author and coauthor of numerous scientific and professional papers in the fields of management and innovation.

Radmila Bjekić is a teaching assistant at the Department of Management, Faculty of Economics in Subotica, University of Novi Sad. She is a student of doctoral studies at the Department of Business Economy and Management module Entrepreneurial Management at the Faculty of Economics in Subotica, University of Novi Sad. She teaches exercises for the courses of Organisational Theory and Organisational Design (undergraduate studies). She is an author and co-author of papers in the fields of human resource management and organization of enterprises, which were published in national and international journals.

Bojan Leković is research assistant at the Department of Management, Faculty of Economics Subotica, University of Novi Sad, Republic of Serbia, where he teaches bachelor's courses in Entrepreneurship and Project Management, and master's course Innovation management. He has taken part in many national and international scientific and research projects. In addition, he is an author and coauthor of numerous scientific and professional papers in the fields of entrepreneurship, project management and innovation management. 